Art Documentation, 2008, v. 27, n. 1, p. 24-27.

ISSN: $0730-7187$

Link to publisher website.

Link to journal table of contents.

(C) 2008 ART LIBRARIES SOCIETY OF NORTH AMERICA.

\title{
Tickling the Ivory Tower: Toward a Salon Culture in Libraries
}

\section{Amanda Gluibizzi}

\section{Introduction}

Even though art librarians work in settings where print resources continue to be important, they face many of the same problems that their colleagues in other libraries do. Determining methods of presenting themselves and the resources to patrons in an attractive and compelling fashion and reminding them of the library's pertinence is a challenge for librarians that touches every institution and collection. As a September 2007 thread on the ARLIS-L listserv ${ }^{1}$ — which discussed one library's invitation to patrons to scream in the library - makes clear, there remains a belief about what cannot be done at the library, which can translate into what the library cannot do for its users. Like those who opened the library to voices and enjoyment, all librarians need to focus attention on making the users comfortable, the library hospitable, and the resources visible. ${ }^{2}$ This article explores the possibilities of building a salon culture in libraries that is focused on people, cultural production, and the interaction between librarians and the public as a form of conversation. It also examines the importance of the librarian in building a library salon culture, the opportunity to perceive the library resources as a conversational element, and the library as a conduit for cultural production. Included are examples of some of the initiatives begun at the Fine Arts Library at The Ohio State University to build participation in the library salon.

\section{The Salon in the Library}

In an April 2007 interview on the radio program "Smart City," Paul Holdengräber, the director of public programs for the New York Public Library, discussed his philosophy for creating a dialogue between the library and its constituents. ${ }^{3}$ Holdengräber's program, "Live from the NYPL," has reinvigorated the library's public contact with the city and has made it a competitor for "the" place to be on weeknights in the city. He advised setting up a conversation between groups on stage, in the library, and throughout the city to instigate a creative tension because, as he put it, "You can't tickle yourself."

Although Holdengräber is reluctant to call what he is organizing a salon, the model of conversation and gathering place that a salon exemplifies can prove to be enlightening for librarians as they re-envision the ways that the field can be vital for patrons and for communities. The salon is about the people who attend; therefore, the library as salon may be about the patrons who use the resources, the authors and artists whose cultural products are found within the collections, and the librarian who is the host and the facilitator of access to such materials. ${ }^{5}$ Art 
librarians and other subject specialists in particular are uniquely poised to be the hinge on which attractive aspects of the library pivot.

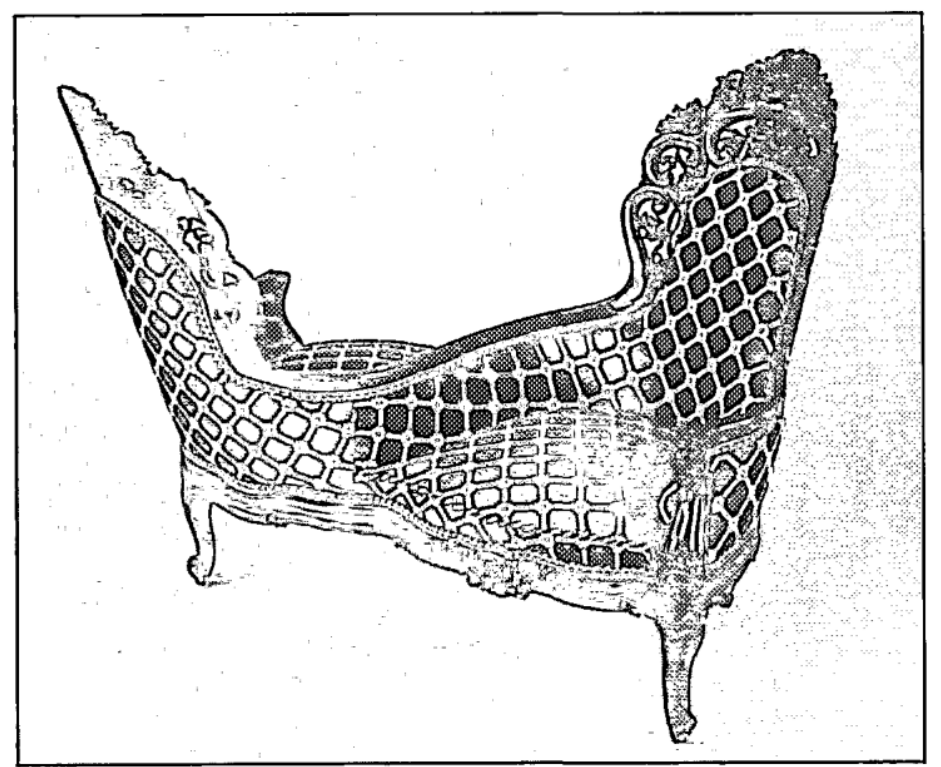

"A mid-nineteenth-century French form, the tête-à-tête, also known as a confident, was well-suited to the parlor as its two chairs facing in opposite directions and joined at the sides allowed for discreet conversation." (Information taken from http://www.metmuseum.org/Works_of_Art/collection_database/). Attributed to, John H. Belter, 1804-1863.

Tête-à-tête. ca. 1850-60. The Metropolitan Museum of Art, New York. Rosewood, ash, pine, walnut.

$44^{1 / 2} \times 52 \times 43$ in. (113.0 x $\left.132.1 \times 109.2 \mathrm{~cm}\right)$ Gift of Mrs. Charles Reginald Leonard, in memory of Edgar Welch

Leonard, Robert Jarvis Leonard, and Charles Reginald Leonard, 1957.

57.130.7. ARTStor: TMSSQL02.american:8781. Image ${ }^{\circledR}$ The Metropolitan Museum of Art.

\section{The Importance of the Librarian}

Because of the move toward greater automation of and online access to library collections and the world's information, much has been made of the "crisis" in librarianship. ${ }^{6}$ Librarians have published articles stressing the importance of library as space and librarianship as an information-and-idea profession. ${ }^{7}$ The facts are, however, that the importance of libraries goes beyond their spaces, and that libraries are not the only places where ideas can germinate. Even the most famous libraries of the past grew their reputations not by having everything ever produced although some aspired to that — but by the fact that what they collected had an intellectual life beyond the physical constraints of the library.

What links the libraries of the past with those of the future, therefore, is often the figure of the librarian, as it is the librarian who is most familiar with his/her constituency and is able to develop collections and programs accordingly. Holdengräber, however, is not a librarian, which makes his success particularly important to examine. How has he succeeded in making the library such a draw without relying on the opportunity to build collections? The key, it seems, is his insistence on being an "instigator." ${ }^{8}$ He does not see the NYPL's programs as passive, but rather expects that they will take on a life of their own at his and his participants' prodding. It is important to realize, too, that Holdengräber's role as instigator demands that he be as much of an actor in his programs as are the authors, artists, and public figures he enlists. This notion of equality between 
him, his participants, and his audience is vital to building an energetic and thoughtful program. Because they are members of a service profession, too often librarians can be construed as support staff or as cheerleaders - positive encouragers at the sidelines but not active participants in the development and consumption of knowledge. Their initiation of and participation in the conversation is vital to the successful promotion of libraries and their resources.

\section{Conversational Elements in the Library}

In his book Conversation: A History of a Declining Art, ${ }^{9}$ Stephen Miller identifies one of the biggest hindrances to enriching conversation: a lack of equality between the conversants. If either one perceives the other or himself/herself as lesser, then conversation and comradeship cannot thrive. So this issue is not simply about conducting a model reference interview or understanding the way that Boolean operators work. It is about becoming a force in the field and at institutions, and about examining not only how librarians are perceived, but also how they present themselves. How do they market themselves and their libraries? Do they leave their offices, or do they expect patrons to come to them? Do they pay attention to the way that patrons perceive them? Do they even give patrons the opportunity to know what they can do for them and for the institutions?

It is in that last instance that subject specialists can prove incredibly pertinent. When I give a tour of the library, I not only take the students and faculty through our collections and online resources, but put forward examples of how my knowledge of and experience in art and art history can be an additional resource for them. I let them know that I can answer questions that databases, Google, and sometimes even their professors cannot. In addition, I always offer the possibility of studio visits to those students who are using the library primarily for visual reference. Because I must be a generalist within my subject specialty, I am able to field questions such as, "Whose paintings look like they were done with a milky medium?," "Why isn't video art boring?," and "What artists does my work look like?" Because of this generalist status, I can also be the best sort of dilettante, one who embraces everything and can choose what aspects I think deserve my focus. The services offered can extend outside of the library and do not have to be linked to books or databases. Librarians are able to have such rich intellectual lives because of their positions as purveyors of knowledge. The trick is to let the users know that librarians are themselves such resources. As Holdengräber remarked in his interview, good conversation is "rigorous and playful" simultaneously and demands critical engagement "at the highest level." ${ }^{10}$ Librarians are the people who can spark the conversation.

One of the opportunities librarians possess to promote conversation readily and understandably is to bring the resources into the equation. Whether digitally or through print materials, the ideas and images contained within the resources often need to be contextualized in order to make them pertinent for the users. This requires librarians to reexamine two aspects of their roles. First, do they see the reference encounter as being about finding the right answer for patrons, or as about an opportunity for knowledge discovery (or both)? As a subject specialist, I have the opportunity to see every encounter as a way to bring art and artists to the forefront for my patrons. This is especially important for studio art patrons and art historians. They are not simply looking for the "correct" solution (e.g., "What artists "used light as a medium?") but are looking to place themselves in the schema of art history and art understanding and production (e.g., "Where does my analysis of light fit into the greater discourse about art and artists?"). Our collections are 
conduits for communing with artists and artwork and may act as substitutes when the originals are not available to our users, depending on their situations and our institutions' locations. ${ }^{11}$ They enable the library to become a stand-in for the museum, the concert hall, or the city square, even if the objects or experiences represented within them happened long ago or far away. A resource in use is a "sign" for library patrons of artists' work or for an encounter with artists themselves.

That a library resource can signify an artist's oeuvre compels the librarian to provide context for the user. This could involve presenting information about the milieu in which Caravaggio created his paintings or explaining the history that prompted Nancy Spero's work. It is also incumbent on librarians to enable patrons to discover the original context in which their information was found. An image identified in a database did not originate there or with the $35 \mathrm{~mm}$ slide from which the digital image was taken. It may have had text surrounding it in a book or an essay that provided critical or historical discussion about what that image represents. And the image did not start there, either - it began as a work of art that can be placed in a collection, an oeuvre, a historical moment. In an essay from his book Between the Eyes: Essays on Photography and Politics, David Levi Strauss urges his readers not only to look at the images in news stories, but also to see where they are located within the text; how they function with the typographic choices, the captions, the masthead; and even what advertisements surround them. ${ }^{12}$ It is in a print collection that we can find Lynda Benglis's infamous nude exhibition announcement that precedes the pinup image of the artist chosen to illustrate the article about Benglis appearing in the same issue of Artforum. The two images tell the reader quite a lot about Benglis and editorial decision-making in 1974, and it may be up to the librarian to tell patrons about the context they cannot find through a database. ${ }^{13}$

\section{Library as Cultural Producer}

In the eighteenth century, women became salonistes because of social connections or aesthetic interests, and also because a saloniste was a role in the home with which women could wield influence and develop a connoisseurial attitude in their cultural lives. ${ }^{14}$ In the twenty-first century, libraries can help users to become connoisseurs through conversations with librarians, collections, and the programs that are produced. Libraries are challenged today to demonstrate their relevance because they are such consumers of resources without readily visible returns. The salon model does not only consume cultural (and monetary) capital, but produces it as well.

Paul Holdengräber, of course, benefits from the NYPL's location in the middle of Manhattan in terms of opportunities for partnership and potential audience. As a librarian in the middle of Ohio, I do not have the access to the breadth of players that he does. However, there are opportunities in every library and within every budget to become a cultural producer. First, how does the library market itself? What is the library "brand," and what can visitors expect to get out of it? Librarians need to examine their spaces, both actual and virtual. Are materials accessible? Is way-finding easily understandable via signage or encounters with staff? Does the patron feel comfortable to enter the space? Are promotional materials up-to-date and legible? Library Web sites may be even more difficult to make attractive and usable by patrons. In her article describing library Web sites as virtual "third places," in which space is operable and all varieties of people are welcome, Karen Lawson notes that the design of a library Web site is critical to its navigation, to the methods patrons learn to use it and to find resources, and to encouraging patrons to come back. ${ }^{15}$ In reference to library home pages, Mies van der Rohe's dictum "Less is more" is 
incredibly apt. Library Web sites are often too wordy. Instead of informing the typical patron, they may in fact be confusing or discourage browsing. ${ }^{16}$ Librarians know all of the information they want to communicate to patrons. It is important that they also focus on how they are doing so in order to make that information more accessible. In my library, we are currently redesigning the homepage in several ways. We are using color to delineate different areas of knowledge inquiry (e.g., research areas versus frequently-asked questions). We are reassessing the images we use to be certain they are pertinent for our site's visitors and are not visually noisy, and we are working to fit all necessary information on the initial view of the page. The maxim that important stories should go above a newspaper's fold holds true for Web sites as well. If a patron must scroll down to find more information, that information may never be found.

In addition to the Web page that features the catalog search box, many universities and institutions are adding Hogging programs or wikis to their sites. These require little knowledge of HTML and can work well as vehicles for the promotion of a library's focus and intents while allowing visitors to become involved if they so choose. It is important, once again, to think about a context and to provide an online space that patrons will actually want to visit, something that I and my co-workers considered when developing our library blog. ${ }^{17}$ Working under the suspicion that, if we blogged about what was happening in the library, only librarians would be interested (and perhaps not even librarians), the Fine Arts Library bloggers at Ohio State do not even mention the library. ${ }^{18}$ The blog is an arts and culture space wherein we discuss current events and cultural happenings and have running features such as the "Shoe of the Week" in art, attempts to answer "The Big Questions" about artists and their work, and a weekly listing of the happenings around the metropolitan area. While the idea of a cultural blog is not new, the idea that a library does not have to preach to the library-converted is an interesting experiment and one that has proven successful for us. It provides a place for the library to exhibit character and hint at a sense of humor. That it is our sense of humor provides the library staff with another way to connect with our patrons.

Beyond Web sites and blogs, art librarians can have many opportunities to create a dynamic relationship with their communities. Institutions may have well known faculty, alumni, or visiting artists around whom programs can be built. Even barring that, there may be artists, works, or techniques that are particularly important to the institutions. Finding a way to promote and exploit those interests, even if only by displays or targeted collecting, will prove vital for building constituencies. Patrons need to know that librarians are responding to them the first time they visit; their needs must be anticipated the next time. At the Fine Arts Library we are considering developing a seminar program based on readings of the Pop Art explosion. This would pay homage to a famous Ohio State alumnus, Roy Lichtenstein, but it would also be a way to invite scholars and artists to the university and the Fine Arts Library, and would allow us to produce scholarship. I am a faculty member early in my tenure pursuit; if I present this seminar to potential participants as an opportunity for other young faculty to build their curricula vitae, then it may build interest outside of the library staff and possibly outside of Ohio State University. It could also develop a network of scholars, at the center of which would be the library and its resources.

\section{Conclusion}

Building a library salon culture must begin with the librarian. The best spaces and collections will not reach patrons if librarians do not promote them, if they are not excited about 
them, and if they themselves are not regular users of them. They need to give patrons the opportunity to ask about online resources and books, and then to go further and allow them to garner librarians' opinions about the ideas found within those materials. It is not about being pedantic, but it is about being intellectually available and aware. It is also about building the library into an "anchor institution," a flagship around and within which cultural activity can flourish. When asked what impact a library should have on its community, Paul Holdengräber responded that the library should be "irresistible... hospitable. [It should] welcome you the minute you walk in the door" and it should "remind you that this is your inheritance." ${ }^{19}$ The library salon does not have to be a place. It is a state of mind.

\section{Notes}

1. Joan Benedetti et al., postings to Art Libraries Society of North America discussion list, September 6-7, 2007, http://lsv.uky.edu/scripts/wa.exe?A2=ind0709\&L=arlis-J\&T=0\&F=S=\&P=1797

2. Although it was written for business situations, Danny Meyer's discussion of the creation of a hospitable venue has been valuable to my research. Much of his book is common-sense (and some of it reads like a self-help manual), but it is still a good place to start thinking about the possibilities of hospitality in libraries. Danny Meyer, Setting the Table: The Transforming Power of Hospitality in Business (New York: HarperCollins, 2006).

3. Paul Holdengräber, interview by Carol Coletta, Smart City, smartcityradio.com. April 19, 2007.

4. Ibid.

5. In a discussion of the experiences of a European art historian versus those of an American counterpart, Erwin Panofsky described American libraries and art librarians thusly: "He was amazed that he could order a book at the New York Public Library without being introduced by an embassy or vouched for by two responsible citizens; that libraries were open in the evenings, some as long as until midnight; and that everybody seemed actually eager to make material accessible to him... Librarians... seemed to consider themselves primarily as organs of transmission rather than 'keepers' or conservateurs." Erwin Panofsky, "Three Decades of Art History in the United States: Impressions of a Transplanted European," College Art Journal 14, no. 1 (1954):12.

6. See, for example, articles such as Candy Hillenbrand, "Librarianship in the 21st Century: Crisis or Transformation?" Australian Library Journal 54 (2005): 164-81.

7. See Karen Antell and Debra Engel, "Conduciveness to Scholarship: The Essence of the Academic Library as Place," College and Research Libraries 67, no.6 (2006): 536-60 for a recent examination of the importance of the physicality of the library.

8. This is Holdengräber's term for his role in the conversation, preferring it to moderator, which suggests a lack of engagement. See the Web site for Live from the NYPL for a list of participants in the programs thus far and for transcripts and audiovisual files. New York Public Library, Live from the NYPL, http://www.nypl.org/research/chss/pep/index.cfm.

9. See Stephen Miller, Conversation: A History of a Declining Art (New Haven: Yale University Press, 2006), and particularly chapter 1 , "Conversation and Its Discontents," pages 1-28.

10. Holdengräber, April 19, 2007.

11. Megan Macken made a similar point, albeit tangentially, in her article "The Art Library as Place: The Role of Current Space Planning Paradigms Within the Academic Art and Architecture Library," Art Documentation 25, no.2 (2006): 19.

12. David Levi Strauss, "Photography and Propaganda," in Between the Eyes: Essays on Photography and Politics (New York Aperture, 2003), 12-41. As Levi Strauss points out, we can often learn about the politics of the editorial staff members and their relationships to their advertisers by noticing the way that advertisements interact with the stories.

13. See Robert Pincus-Witten, "Lynda Benglis: The Frozen Gesture," Artforum 13, no.3 (November 1974): 54-59, as well as the advertisement for Benglis's one-woman show at Paula Cooper Gallery that ran in that issue.

14. For recent histories of the development of salons, see Benedetta Craveri, The Age of Conversation (New York: New York Review Books, 2005) and Jesse Browner, "Conversation Starter," Bookforum 14, no.3 (September/October/November 2007): 12-13. 
15. Karen Lawson, "Libraries in the USA as Traditional and Virtual 'Third Places,"' New Library World 105 (2004): 127-28. Lawson's reference to libraries as "third places" builds on Ray Oldenburg's book The Great Good Place: Cafes, Coffee Shops, Community Centers, Beauty Parlors, General Stores, Bars (New York: Marlowe \& Co., 1997). Interestingly, Oldenburg himself does not examine libraries as third places.

16. My own thinking about library Web sites and the way they may be used and understood by our patrons has been informed by David Crow, Left to Right: The Cultural Shift from Text to Image (Lausanne: AVA Academia, 2006) - understanding, of course, the irony of reading a book about such a topic.

17. Gretchen Donelson and Amanda Gluibizzi, Fine Arts Library Blog, http://library.osu.edu/blogs/finearts/.

18. Although our decision not to blog about the library was made before I began research for this article, the decision mirrors Holdengräber's thinking for his programs: "I wanted to go beyond academic discourse and speak to a very large public, and to the common reader." Paul Holdengräber as quoted in Dinita Smith, "In the Age of the Overamplified, a Resurgence for the Humble Lecture," New York Times, March 17,2006, sec. E.

19. Holdengräber, April 19, 2007.

\section{Additional Sources Consulted}

Comita, Jenny. "Not Just Talk." W Magazine, February 2007, 148.

Ivins, William M., Jr. "In the Beginning Was the Word." The Metropolitan Museum of Art Bulletin, New Series 4, no.1 (1945): 12-17.

Kale, Steven D. "Women, the Public Sphere, and the Persistence of Salons." French Historical Studies 25, no.l (2002): 115-48.

Ray, William. "Talking About Art: The French Royal Academy Salons and the Formation of the Discursive Citizen." Eighteenth-Century Studies 37, no.4 (2004): 527-52.

Thompson, J. Michael. "ACRL 11th National Conference: Focusing on the Future with an Eye to the Salons of the Past." Library Collections, Acquisitions, \& Technical Services 27, no.3 (2003): 351-65.

Valdes, Marcela. "Hot Times at the Library." Publishers Weekly 253, no.3 (January 16, 2006): 22-3. 